\title{
The need for pension reform in Russia
}

\author{
Galina Semenova ${ }^{1,2, *}$ \\ ${ }^{1}$ Plekhanov Russian University of Economics, 36, Stremyanny lane, Moscow, 117997, Russia \\ ${ }^{2}$ Moscow Region State University, 24, Very Voloshinoy street, city of Mytishi, Moscow region, \\ 141014, Russia
}

\begin{abstract}
The relevance of the paper is caused by the fact that the current pension system did not satisfy either citizens, since their pensions were extremely miserable, neither employers due to the high level of contributions to the Pension Fund of the Russian Federation, nor the government, since the low level of pensions caused social and, as a consequence, political tension, nor the subjects of the Russian Federation, since the unfunded pension system obliged the regions to deduct funds from their own funds to cover pension obligations to subsidized regions. The way out of this situation is the creation of a new pension reform, which will increase the size of the pension by increasing the income of the pension system itself. The main goal of the pension reform is to increase the welfare of Russian citizens after they retire. The subject of the study is a new pension reform, the stimulus of which was to become a transition from an unfunded to a defined contribution pension system. The aim of the study is to identify the main economic reasons for creating a new pension reform. Methodology. To study the new pension reform, the main indicators are systematized: the minimum length of service for assigning an insurance pension, the amount of pension points for the period from 2015 to 2024 and subsequent years, and pension calculation formulas. Results. According to the new pension reform, the employee is encouraged to show full salary for employers to pay insurance contributions. The conditions are created to remove real wages from the "shadow". The unfunded pension system caused social instability, caused a conflict of generations, workers and employers, destabilized the authorities. The new pension reform is designed to provide conditions for mutual assistance of generations and social partnership. The unfunded pension system led to the fact that pension payments were a heavy burden on the economy. The new pension system, at the expense of the funded part of the insurance contribution, creates an investment resource of "long money" (with a demand period of 25-30 years). Thus, the pension system not only serves elderly citizens, but also really works to develop the domestic economy.
\end{abstract}

\section{Introduction}

Pension reform is a deliberate policy of the state related to changes in the current legislation and aimed at changing the conditions of pension provision.

\footnotetext{
*Corresponding author: Sg6457@mail.ru
} 
The planned actions for the implementation of the pension reform in 2018 are based on the decree of the President of the Russian Federation of May 7, 2018 No. 204 "On national goals and strategic objectives of the development of the Russian Federation for the period until 2024". The Russian Government was given a series of instructions reflecting the essence of the pension reform: halving the level of the poorand preventing this threshold from being raised by people on well-deserved retirement, increasing the growth of payments ahead of the inflation rate, creating and introducing federal and regional programs to support pensioners and increase the quality of life of Russian citizens.

Based on this, starting January 1, 2019, the Government of the Russian Federation will begin to implement measures to stabilize the system by increasing contributions to $40 \%$ of wages. This should be influenced by indexing almost two times higher than annual inflation. In addition, the planned volume will be influenced by an increase in access to well-deserved rest within five years.

Additionally, there are plans to develop and implement a system of personal capital formation in old age. The system of individual pension coefficient (IPC) will act as an alternative to the funded part and in the future should increase the size of payments by old age by $15 \%$. If the reform process of some aspects related to pensions is not carried out, a situation arises of the need to increase insurance contributions to the Pension Fund of the Russian Federation from $22 \%$ to $26 \%$.

Nowadays, there is such an economic situation in Russia that affects pension accruals. Every 120 citizens who officially work on the territory of the Russian Federation maintain 100 pensionerswith the help of their contributions to the Pension Fund of the Russian Federation. If we take other countries as an example, the situation in them is much better. The same number of working people can provide 150 retirees who have gone on a welldeserved rest [1].

\section{Materials and Methods}

The positive aspect of recent years is that, despite the unstable and crisis situation in Russia, the unstable economic situation due to sanctions from many countries and organizations, the average life expectancy is growing. According to statistics, in 2015, the average life expectancy of Russian citizens was 71.4 years (for men - 65.9, for women - 76.5 years). 5 years before, in 2010, the average life expectancy of citizens in Russia was 68.94 years [2].

Nowadays, it can be stated that in 2019, Russia will set a record for average life expectancy, which will exceed the mark of 72 years in life expectancy. According to Deputy Prime Minister Olga Golodets, such results were achieved due to systematic work based on lowering mortality among citizens (compared with last year, the number of deaths per 1,000 people decreased from 13.2 to 12.9 people). In the future, according to the Deputy Prime Minister, the issue of the demographic situation in Russia will remain a priority $[7,8]$.

Three countries can be distinguished - the record holders for the total life expectancy among citizens are Japan with an indicator of 84.6, Switzerland - 83.4, Germany - 83.1. The largest average life expectancy among men is recorded in Switzerland and is approximately 83.1 years on average. The country who is the record holder for life expectancy among women is Japan, with an indicator of 86.8 years. According to the general rating of data for 2015 , Russia ranks 110 th in the average life expectancy among citizens with an indicator of 71.4 years [6].

In Russia, the number of pensioners is growing steadily every year. Therefore, the funds for the payment of pensions in the federal budget are constantly in short supply.

The main sources of funds for the payment of pensions to Russian pensioners are insurance contributions that all employers pay from employee benefits in the framework of 
labor relations. Insurance contributions are credited to extrabudgetary funds for pensions, social and medical insurance [7].

Insurance contributions to extrabudgetary funds are growing annually. For example, insurance contributions for compulsory social insurance in 2018 amounted to 6,417 billion rubles, which is $10.6 \%$ more than in 2017 (Fig. 1). Of these, the contributions received in the Pension Fund of the Russian Federation in 2018 amounted to 4,958 billion rubles, or $10.4 \%$ more than in 2017 [7].

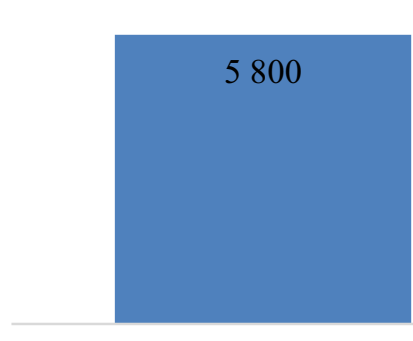

2017

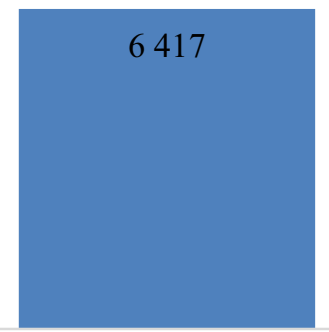

2018

Fig. 1. Insurance contributions for compulsory social insurance in 2017-2018, billion rubles.

Insurance contributions are calculated on the basis of accruals in favor of individuals, established limits of the taxable base and insurance contribution rates.

The interest rate of the tariff depends on the amount taxed by insurance contributions. The higher the employee's salary with a cumulative total during the tax period, the lower the rate of insurance contributions from the salary for the employer (table 1).

Table 1. Insurance contributions from the salary paid by employers to extrabudgetary funds in 2019.

\begin{tabular}{|l|l|c|}
\hline \multicolumn{1}{|c|}{ Insurance contributions } & \multicolumn{1}{c|}{$\begin{array}{c}\text { Limit value of the base for } \\
\text { calculating insurance } \\
\text { contributions, rubles, per year }\end{array}$} & Tariff rate, \% \\
\hline $\begin{array}{l}\text { For compulsory pension } \\
\text { insurance }\end{array}$ & up to 1,150,000 rubles inclusive & 22 \\
\cline { 2 - 3 } & up to1,150,000 rubles & 2.9 \\
\hline \begin{tabular}{l} 
For compulsory social $\begin{array}{l}\text { insurance in case of temporary } \\
\text { disability and motherhood }\end{array}$ \\
\cline { 2 - 3 } $\begin{array}{l}\text { For compulsory health } \\
\text { insurance }\end{array}$
\end{tabular} & over 865,000 rubles 865,000 rubles inclusive & 0 \\
\hline
\end{tabular}

Attempts to reanimate the old structure of the Russian pension system (including with the adoption of new laws on insurance and funded pensions in 2013, which entered into force on January 1,2015) failed, primarily due to a new wave of financial and economic crisis and the fall of the world oil prices [4].

In Russia, the indexation of pensions for working pensioners has been suspended since 2016. According to the adopted budget for 2018-2019, the indexation of insurance pensions will rise and exceed the percentage of inflation. The budget includes the amount for pension payments.It will grow by more than 270 billion rubles in two years [5].

The need for changes in the pension system has been discussed by the Government of the Russian Federation for quite some time. In his speech to the State Duma deputies on May 8, 2018, Prime Minister Dmitry Medvedev suggested moving from discussions to concrete actions (primarily on the most pressing issue of raising the retirement age). The 
need for change is justified, first of all, in the changing social and economic situation in the country.

Therefore, in the spring of 2018, the Government of the Russian Federation announced the launch of a new pension reform in Russia, which begins to be implemented in 2019 . The first stage of the next reform will be raising the retirement age to 65 for men and 60 for women. Such a law was adopted and signed by Russian President Vladimir Putin on October 3, 2018. Among the most important reasons for the new pension reform, the following can be distinguished:

1. The life expectancy of Russians has changed. At the time of establishing the current retirement dates in the USSR (when reaching the age of 55 for women and 60 for men), the average life expectancy of citizens was a little over 40 years. For the first half of 2019, the forecast is 72.4 years.

2. In the Decree No. 204 of 07.05.2018, Russian President Vladimir Putin set the goal of increasing life expectancy to 78 years by 2024 , and by 2030 - to 80 years.

3. The share of pensioners in the population structure is increasing annually. Russian Federal State Statistics Service (Rosstat) predicts that by 2030, the number of employable citizens will decrease by 4 million people.

4. There are not enough funds in the federal budget for the implementation of national projects of 2018-2024. For their implementation, the Government of the Russian Federation needs to find somewhere additional 8 trillion rubles (which is half of the annual budget of Russia) for the next 6 years (until 2024). Funds saved as a result of the pension reform can be used to cover this budget deficit.

5. The system of funded pensions that have not been working for several years. In 2014, contributions to the funded part of the pension were "frozen" for the first time, i.e. for several years now, all employer pension contributions for their employee have been directed only to the Pension Fund for insurance pension and do not fall into the pension savings system (i.e. the funded pension of Russians is not formed from their wages for several years).

The minimum pension in Russia in 2019 for non-working pensioners will correspond to the subsistence minimum of the pensioner (hereinafter referred to as the SMP), effective from January 1, 2019, calculated on the basis of the consumer basket for food and non-food products.

In 2019, the country's average SMP is set at 8,846 rubles. Each region sets its own SMP. For example, the size of SMP in the Moscow region is 9,908 rubles, in Moscow it is 12,115 rubles per month - this is higher than the all-Russian living wage. The largest minimum pension payments have been established for regions belonging to the Far North and the Far East, such as, for example, in the Murmansk region - 12,674 rubles, Kamchatka Krai - 16,543 rubles, Republic of Sakha (Yakutia) - 13,951 rubles, Magadan. - 15,460 rubles, Chukotka Autonomous Okrug - 19,000 rubles. [7].

In other regions, pension payments are lower and differ from the all-Russian SMP. For example, in the Republic of Tatarstan - 8,232 rubles, Nizhny Novgorod region - 8,102 rubles, Astrakhan region - 8,352 rubles, Yaroslavl region - 8,163 rubles, Tambov region 7,811 rubles, Belgorod region - 8,016 rubles, Stavropol Krai - 8297 rubles, the Republic of Kalmykia - 8081 rubles, Penza region - 8404 rubles, Saratov region - 8278 rubles. The living wage of a pensioner in such "poor" regions remains very low [7].

To apply for pension insurance contributions, three prerequisites must be met. The first condition is to achieve the retirement age established by the new rules.

The second condition is the existence of a minimum level of insurance experience, which is provided for by the pension reform (annual increase in the minimum length of service to 15 years by 2024) (Table 2). 
Table 2. Minimum length of service for assigning an insurance pension.

\begin{tabular}{|c|c|}
\hline $\begin{array}{c}\text { Year of an old-ageinsurance } \\
\text { pensionprovision }\end{array}$ & $\begin{array}{c}\text { Minimum length of service required for an old- } \\
\text { age insurance pension }\end{array}$ \\
\hline 2015 & 6 years \\
\hline 2016 & 7 years \\
\hline 2017 & 8 years \\
\hline 2018 & 9 years \\
\hline 2019 & 10 years \\
\hline 2020 & 11 years \\
\hline 2021 & 12 years \\
\hline 2022 & 13 years \\
\hline 2023 & 14 years \\
\hline 2024 and next years & 15 years \\
\hline
\end{tabular}

The third condition is the amount of pension points (IPC) (not lower than 6.6 with a subsequent annual increase of 2.4 to 30 points by 2025) (Table 3 ).

Table 3. The value of pension points (IPC).

\begin{tabular}{|c|c|c|c|c|c|c|c|c|c|c|c|}
\hline $\begin{array}{c}\text { Retirement } \\
\text { year }\end{array}$ & $\stackrel{n}{\stackrel{2}{2}}$ & ํㅜㄹ & $\stackrel{5}{\frac{1}{7}}$ & $\stackrel{\infty}{\stackrel{N}{7}}$ &  & ฮั๊ & $\overline{\widetilde{N}}$ & ָ̃ & ֻิ & 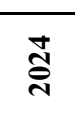 & 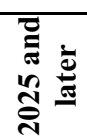 \\
\hline $\begin{array}{l}\text { Minimal } \\
\text { coefficient }\end{array}$ & 6.6 & 9.0 & 11.4 & 13.8 & 16.2 & 18.6 & 21.0 & 23.4 & 25.8 & 28.2 & 30.0 \\
\hline
\end{tabular}

When analyzing the size of pensions, it should be borne in mind that the same amount in different countries provides a different standard of living. The average pension in Russia and in other countries is shown in Fig. 2.

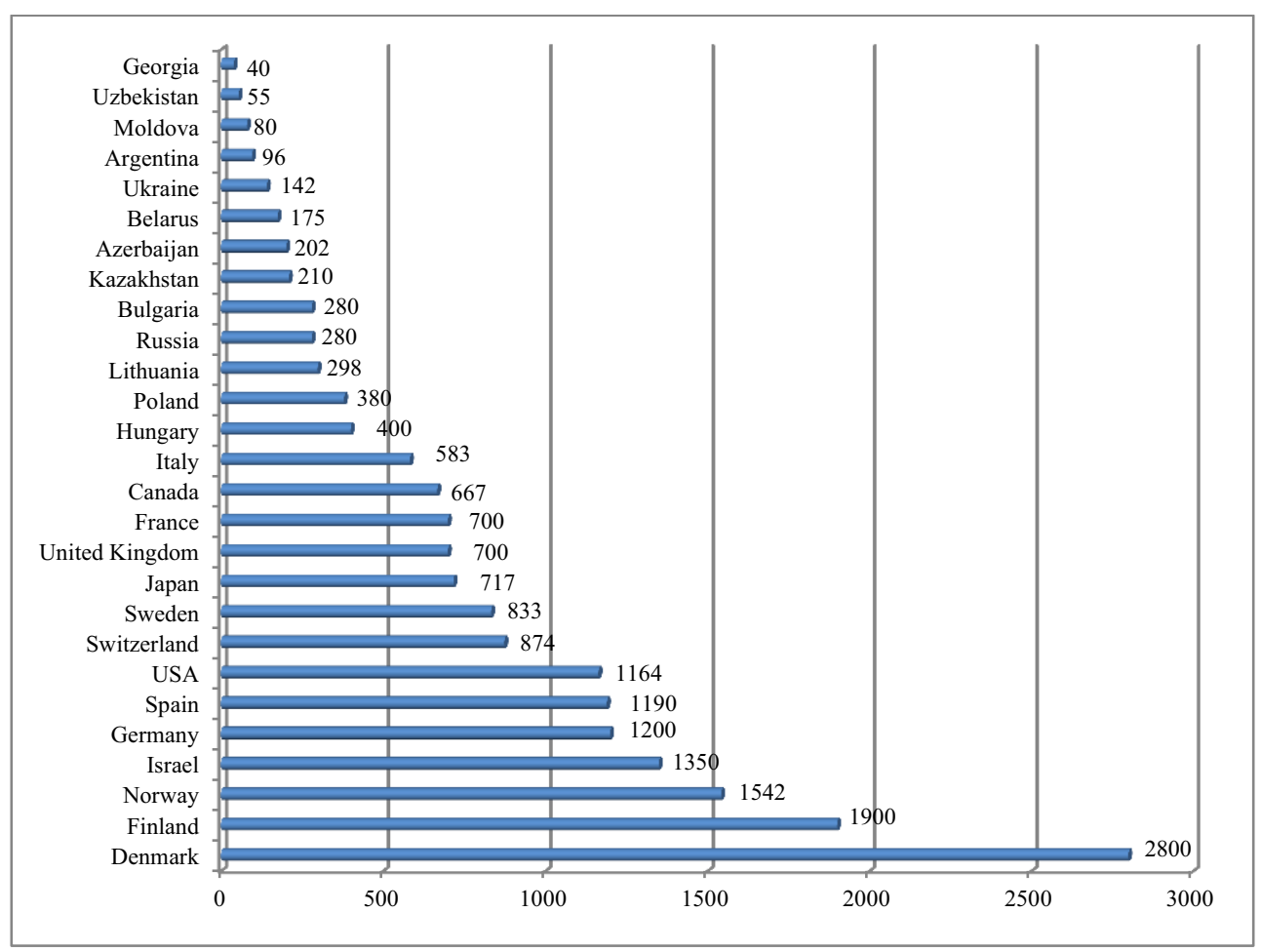

Fig. 2. Amount of average pension in Russia and other countries (dollars/month). 
As can be seen from fig. 2, the average pension in Russia is 280 US dollars, which is approximately 16,800 rubles.

\section{Results}

Russian President Vladimir Putin made an address on August 29, 2018 to the Russian population and made the following changes:

1. To soften the retirement age for women by 3 years (i.e. set the age standard not at 63 years, but at 60 ).

2. To provide citizens who, according to the old law, were able to retire in the next two years (2019-2020), the opportunity to leave 6 months earlier than the new law suggests, i.e. at 55.5 and 60.5 for those who were supposed to apply for the pension according to the old rules in 2019, 56.5 and 61.5 - in 2020.

3. To provide early retirement for persons with long-term insurance (labor) experience: women - 37 years, men - 42 years.

4. To provide for early retirement of mothers with many children: with three children -3 years ahead of schedule, with four - 4 years earlier.

The age at which there is a right to a state pension is shown in table 4.

Table 4. The age upon reaching which there is a right to a state pension provision.

\begin{tabular}{|l|l|l|}
\hline \multirow{2}{*}{$\begin{array}{c}\text { The year in which the citizen acquires } \\
\text { the right to a state pension provision } \\
\text { as of December 31, 2018 }\end{array}$} & \multicolumn{1}{|c|}{$\begin{array}{c}\text { The age upon reaching which there is a right to a } \\
\text { state pension provision }\end{array}$} \\
\cline { 2 - 3 } & \multicolumn{1}{|c|}{$\begin{array}{c}\text { Men } \\
\text { Women }\end{array}$} \\
\hline 2019 & $\mathrm{~V} *+12$ months & $\mathrm{V}+12$ months \\
\hline 2020 & $\mathrm{~V}+24$ months & $\mathrm{V}+24$ months \\
\hline 2021 & $\mathrm{~V}+36$ months & $\mathrm{V}+36$ months \\
\hline 2022 & $\mathrm{~V}+48$ months & $\mathrm{V}+48$ months \\
\hline 2023 and next years & $\mathrm{V}+60$ months & $\mathrm{V}+60$ months \\
\hline \multirow{2}{*}{$\begin{array}{l}\text { V }- \text { the age upon reaching which there is a right to a state pension provision as of December } 31, \\
2018\end{array}$} &
\end{tabular}

But the sizes of the fixed payment and the cost of one coefficient, which are annually indexed by the state, are also taken into account. In 2019, such indexation has already been carried out - fixed payments have been increased by $7.05 \%$ since January 1 . That is, the amount of the insurance pension in 2019 is already determined taking into account the increased sizes of the fixed payment and the pension point. However, this concerns only non-working pensioners [3].

The number of accumulated coefficients depends on the amount of insurance contributions (IC), which the employee deducts to the Pension Fund from his salary. Accordingly, the longer the work experience and the higher the salary, the more insurance contributions, and therefore the greater the individual pension coefficient (hereinafter IPC).

The cost of one pension point (IPC) and a fixed payment (FP) is set by the state. Each year, these values are indexed in accordance with the level of inflation in the country, so the pension provision of Russians is increasing every year.

It is possible to calculate the pension by points in 2019 as follows.

The procedure for calculating pensions will differ depending on the type of security received (old age, disability, or loss of a breadwinner), but the calculation formula in general looks like this:

$$
\mathrm{IP}=\mathrm{CPC} \times \mathrm{IPC}+\mathrm{FP}
$$


where CPC - the cost of one pension coefficient; FP - the cost of a fixed payment; IPC individual pension coefficient (the number of points accumulated by a pensioner over the years of work).

Besides, additional allowances may be assigned to a pensioner for various reasons: for northern experience (for work in the Far North or in areas equivalent to the Far North), for dependents (disabled citizens, children supported by a pensioner), for rural work experience and further living in the village, as a pensioner who has reached the age of 80 years, as living in areas of the Far North or in equivalent localities (an increase by the district coefficient), for disability, and so on.

All of the above allowances are summed up with the amount of pension calculated by the formula. In fact, the formula will look like this:

$$
\mathrm{IP}=\mathrm{CPC} \times \mathrm{IPC}+\mathrm{FP}+\mathrm{A}
$$

where A - various allowances.

Many of the listed allowances are also indexed annually, since their amount is determined based on the amount of the fixed payment (FP). For example, a premium for rural experience is $25 \%$ of the amount of a fixed payment.

The cost of a pension point for calculating a pension is annually determined by the Government of the Russian Federation. Previously, the pension coefficient was indexed annually from February 1, but in the period from 2019 to 2024, it will be indexed from January 1. In January 2019, the index of the pension coefficient has already been indexed, now its cost is 87.24 rubles. It is this value that will be used in calculating the size of the pension in 2019. However, for working pensioners, the cost of one coefficient in 2019 has not changed due to the moratorium on indexing FP and CPC applicable to them.

In addition, from January 1, 2019, the expected term of the funded pension payment will be increased to 252 months (for comparison, this parameter was approved at 246 months for 2018, i.e. it is proposed to increase its value by 6 months in 2019). This parameter directly affects the size of the allowance, which is paid to the pensioner on a monthly basis from his pension savings. The size of this monthly allowance is calculated by the formula:

$$
\mathrm{FP}=\mathrm{PS}: \mathrm{T}
$$

where PS - total pension savings at the time of retirement; $\mathrm{T}$ - period of the funded pension payment (payment period in months).

Consequently, if the expected payment period is increased, then the amount of the monthly allowance from pension savings will become less. These changes are justified by statistics on the so-called "life expectancy of Russians" (life expectancy after retirement) 16.46 years for men and 26.14 for women. Adjustments will affect only those who draw up a monthly payment from the funded part of the pension in 2019 .

Prior to the adoption of the moratorium in 2014, the pension system was based on the fact that insurance contributions for compulsory pension insurance ( $22 \%$ of the salary) were transferred by employers to the Pension Fund and, if desired, could be distributed as follows:

1. $16 \%$ for the formation of an insurance pension (including a fixed payment, which is formed at the expense of the so-called joint part of the tariff - $6 \%$ ) and $6 \%$ for the funded part.

2. All $22 \%$ only for the formation of an insurance pension without the formation of pension savings.

Since 2014, after the moratorium was introduced, all Russians compulsory insurance contributions go only to the formation of an insurance pension, and the influx of money into the funded pension system has been frozen. 
The new voluntary funded system (IPC) implies that the employee will additionally transfer part of his salary (from $0 \%$ to $6 \%$ ) to form his pension capital. It is planned to involve a citizen in the new system voluntarily - at the request of the employee, in which he will independently indicate what percentage of his earnings he is willing to additionally deduct in the form of contributions.

It is worth noting that upon the introduction of the IPC program, the currently active funded system will be canceled. Pension savings of Russians who are in Non-State Pension Funds of the Russian Federation (hereinafter referred to as the NPF of the RF) will be automatically transferred to the IPC system (i.e. credited to the pension capital account). If the citizen's savings are in the State Pension Fund of the Russian Federation (hereinafter the PF of the RF), then they can be [3]:

- transferred to pension points and directed to the insurance part of the pension;

- or during the transition period (it is expected to be 2 years), it will be possible to redirect the accumulations from the PF of theRF to the NPF of the RF, so that the existing accumulations will also be used to form pension capital.

\section{Discussion}

Experts note that by 2030 , the proportion of the disabled population older than retirement age will increase by $2.8 \%$ compared to 2018 (from 38,023.9 thousand people to 41,386.4 thousand people). In turn, the proportion of the working-age population will decrease by $1.7 \%$.

For example, Russian Minister of Finance Anton Siluanov said, "The issue of changing the retirement age is urgent in order to avoid an increase in insurance contributions. And if you don't do this, then it is proposed to increase insurance contributions to $26 \%(+4 \%)$ in 2019". He also emphasized that in Russia, only 120 employees work to support 100 pensioners, in other countries - 150-160. In a few years, the number of pensioners will exceed the number of working citizens.

The Minister of Labor and Social Security of Russia Maxim Topilin said that the time has not yet come for raising the retirement age, since life expectancy in Russia is not very high, and there is a short period for receiving itafter retirement.

According to Dmitry Malykh, the 2019 pension reform should be applied to people who are now under the age of 45 . However, he also notes that there is a high probability that they will encounter a situation where a person will work more for several years than his neighbor, born a year later.

In addition, a number of experts note that with proper preparation and introduction of corrections at all levels, this reform will allow the country to reach a new economic level.

However, there are much more reasons for raising the retirement age. First of all, raising the retirement age can create unemployment risks among young people and older workers, which will affect the poverty level and lower wages in the Russian Federation. In addition, this change may cause an increase in the number of disability pensions (50\% of Russians aged 60 have diseases for which they can apply for a pension).

Experts of the Russian Presidential Academy of National Economy and Public Administration (hereinafter referred to as RANEPA) have developed their own concept of pension system reform in Russia, which generally eliminates the need to increase the retirement age provided that the PF of the RF is financed from the federal budget and insurance contributions are increased by 5 percentage points (thereby increasing the tax burden on employers). If we focus on raising the retirement age, then RANEPA believes that the best option would be to perform the reform according to the following scenario:

- increase the retirement age: up to 60 years for women (i.e. by 5 years); up to 63 years for men (i.e. for 3 years); 
- do this increase smoothly - by 3-6 months per year.

There were also statements of disagreement with the changes proposed by the Government from three "opposition" parliamentary parties (A Fair Russia, the Communist Party of the Russian Federation and the Liberal Democratic Party). They voted against the adoption of this law. State Duma deputies from the Communist Party even introduced their own bill on May 15, 2018, which provides for a moratorium on raising the retirement age until January 1, 2030.

\section{Conclusions}

Reforming the pension system requires an integrated approach. It is impossible to reform the pension system in isolation from the reform of wages and tax systems, the development of the financial infrastructure of the economy and the rise in the real sector of the economy. We can agree with the opinion of Russian President Vladimir Putin that raising the retirement age is a necessary measure.

The following conclusions should be drawn from this: when raising the retirement age, you must first of all think about older people who will find it difficult to find a job, and the labor market is not yet ready for this. For those who cannot find a job, the state will have to pay unemployment and poverty benefits instead of pensions, so the budget will not benefit. Raising the retirement age is good where the economy is dynamic, where enterprises are not being liquidated, and enterprises are created and developed, where they are not bankrupted, but are supported to get out of this situation, where people, having gained vast experienceby the age of 55-60, are needed by the enterprise and the state. After 50 years, finding a job in Russia is not easy.

An increase in insurance contributions from $30 \%$ to $34 \%$ will lead to an increase in costs and cost of production, many entrepreneurs will divert wages to the shadow sector of the economy, the federal budget will not receive taxes and lose more income [7].

The reform of the pension system in Russia and the implementation of the proposed measures will reduce the unfunded component deficit to $1.2 \%$ of the gross domestic productby 2020, and by 2030 it will:

- optimize the deficit of the Russian pension system at the level of $0.9 \%$ of gross domestic product;

- ensure the ratio of the pension to the subsistence minimum of the pensioner - up to 3 pensioners' minimum subsistence minimum in the 2030s with the subsequent progressive increase in this indicator;

- create conditions for increasing the replacement rate of lost earnings by pension to at least $40 \%$ for people who have workeda standard length of service with at least average earnings. At the same time, the individual replacement rate, taking into account additional corporate and individual forms of accumulation, can reach 47-50\% (with 42-45-year work experience - up to $55-70 \%$ ).

\section{References}

1. Pension in 2019 in Russia: the latest news, https://2019god.net/novosti/pensiya-v2019-godu-v-rossii-poslednie-novosti

2. D.I. Bulin, Pension reform: getting a pension will be more difficult, http://www.bbc.co.uk/russian/society/2018/12/131223duma_pensions_reform_approve d.shtml

3. G.I. Moro, On the need for pension reform, http: //viperson 
4. T. Omelchuk, The new pension reform will reduce the size of pensions for all future pensioners, Information and analytical portal AZERROS (2018)

5. V.V. Potapenko, A.A. Shirov, Forecast of the development of the Russian pension system for the period until 2030, http://www.macroforecast.ru/doc/shirov_potapenko.doc.

6. V.D. Roik, The pension system of the Russian Federation: challenges of the XXI century and the path of modernization (Piter, 2018)

7. G.N. Semenova, Economics and entrepreneurship 2(103), 152-156 (2019) https://www.elibrary.ru/item.asp?id=37238638

8. N. Elsebaie, E. Ganebnykh, M. Lunyakov, E3S Web of Conferences 110, 02155 (2019) DOI: $10.1051 / \mathrm{e} 3$ sconf $/ 201911002155$ 